\title{
Graze to grain-measuring and modelling the effects of grazed pasture leys on soil nitrogen and sorghum yield on a Vertosol soil in the Australian subtropics
}

\author{
A. M. Whitbread ${ }^{\mathrm{A}, \mathrm{C}}$ and R. L. Clem $^{\mathrm{B}}$

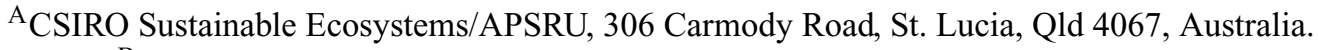 \\ ${ }^{B}$ Queensland Department of Primary Industries, Gympie, Qld 4570, Australia. \\ ${ }^{\mathrm{C}}$ Corresponding author. Email: anthony.whitbread@csiro.au
}

\begin{abstract}
Highly productive sown pasture systems can result in high growth rates of beef cattle and lead to increases in soil nitrogen and the production of subsequent crops. The nitrogen dynamics and growth of grain sorghum following grazed annual legume leys or a grass pasture were investigated in a no-till system in the South Burnett district of Queensland. Two years of the tropical legumes Macrotyloma daltonii and Vigna trilobata (both self regenerating annual legumes) and Lablab purpureus (a resown annual legume) resulted in soil nitrate $\mathrm{N}$ (0-0.9 m depth), at sorghum sowing, ranging from 35 to $86 \mathrm{~kg} / \mathrm{ha}$ compared with $4 \mathrm{~kg} / \mathrm{ha}$ after pure grass pastures. Average grain sorghum production in the 4 cropping seasons following the grazed legume leys ranged from 2651 to $4012 \mathrm{~kg} / \mathrm{ha}$. Following the grass pasture, grain sorghum production in the first and second year was $<1900 \mathrm{~kg} / \mathrm{ha}$ and by the third year grain yield was comparable to the legume systems. Simulation studies utilising the farming systems model APSIM indicated that the soil $\mathrm{N}$ and water dynamics following 2-year ley phases could be closely represented over 4 years and the prediction of sorghum growth during this time was reasonable. In simulated unfertilised sorghum crops grown from 1954 to 2004, grain yield did not exceed $1500 \mathrm{~kg} / \mathrm{ha}$ in $50 \%$ of seasons following a grass pasture, while following 2-year legume leys, grain exceeded $3000 \mathrm{~kg} / \mathrm{ha}$ in $80 \%$ of seasons. It was concluded that mixed farming systems that utilise short term legume-based pastures for beef production in rotation with crop production enterprises can be highly productive.
\end{abstract}

Additional keywords: ley legumes, APSIM, modelling, simulation, mixed farming systems.

\section{Introduction}

In the northern grainbelt of Australia, which includes northern New South Wales and southern and central Queensland, declining soil fertility, poor and variable returns from grain production, and good returns from cattle enterprises have led many farmers to consider the role of ley pastures in their farming systems. Temperate legumes, the deep-rooted perennial lucerne (Medicago sative L.) and the annual Medicago spp., are integral components of some dryland mixed farming enterprises in southern Queensland and northern NSW. However, the use of these legumes in comparable systems in central Queensland is limited by their relatively poor adaptation. The annual species are limited by the low and variable winter rainfall environment that limits seed set (Conway et al. 2001), and lucerne persistence is restricted by hot conditions and wet soils in the summer that exacerbate root rotting diseases (Cameron 1973; Irwin 1974a, 1974b, 1977; Lloyd et al. 1985). The adoption of all Medicago spp. is also restricted by the risk of their causing bloat in cattle (D. L. Lloyd, pers. comm.). As an alternative to these temperate legume species, tropical annual legumes such as lablab (Lablab purpureus cvv. Highworth and Rongai) and cowpeas (Vigna unguiculata) have played a limited role as pasture leys to date.

A number of perennial summer-growing legumes are now known to be well adapted to lower rainfall (700-800 mm mean annual rainfall) areas in central and southern Queensland (Clem et al. 1996, 2001; Jones and Rees 1997; Pengelly and Conway 2000). These legumes have a range of characteristics that complement or provide alternatives to the temperate and tropical species described above. These include perennial legumes such as Milgarra butterfly pea (Clitoria ternatea $\mathrm{cv}$. Milgarra), Endurance lablab (Lablab purpureus cv. Endurance), and burgundy bean (Macroptilium bracteatum cvv. Cardaga and Juanita) described by Whitbread et al. (2005). Self-regenerating legumes such as Vigna trilobata and Macrotyloma daltonii previously tested by the Queensland Department of Primary Industries and CSIRO remain unreleased but may be useful germplasm in the future. 
In a grazed pasture experiment described by Clem (2004) and Whitbread and Clem (2004) the animal production of cattle grazing tropical legumes, mixed perennial legumegrass pastures, and grass-only pastures was measured. This author found that both the longer term perennial legumes that persist with grass, and the forage legumes used in shorterterm leys, could provide high quality forage to finish cattle for premium beef markets.

The aim of this study was to assess the effect of grazed short-term legume leys and grass-only pastures on soil nitrogen dynamics and production of a 4-year grain sorghum phase following these pasture systems. To further understand the dynamics of mineral nitrogen $(\mathrm{N})$, soil water, and crop growth of the sorghum phase, the farming systems model APSIM (Agricultural Production Systems Simulator) (Keating et al. 2003) was used to simulate the soil-plant system and analyse the potential grain production of sorghum following legume or grass pastures over a range of seasons.

\section{Methodology}

As described by Clem (2004), the experiment was located at the Brian Pastures Research Station $\left(25^{\circ} 40^{\prime} \mathrm{S}, 151^{\circ} 45^{\prime} \mathrm{E}\right.$, elevation $\left.136 \mathrm{~m}\right)$ on a moderately to strongly self-mulching Black Vertosol on a $3-10 \%$ slope, Ug5.34 (Northcote 1979), with weak linear gilgai (Reid et al. 1986). From the eight 2.5-ha replicated pasture treatments established in the summer of 1997-98 described by Clem (2004), 4 replicated pasture treatments were selected to test the response of sorghum production following termination of the ley pastures. The treatments selected were the improved grass pasture (Bothriochloa insculpta cv. Bisset, Dichanthium sericeum, and Panicum maximum var. trichoglume cv. Petrie), the annual legume pasture Lablab purpureus cv. Highworth, and the self-regenerating legume pastures Macrotyloma daltonii CPI 60303 and Vigna trilobata CPI 13671. Prior to the establishment of these pasture treatments in 1997-98, the grass treatments had been preceded by a history of grazed grass pasture, whereas the legume treatments had been preceded by $20+$ years of crop production and pasture rotation.

The grass pasture treatments were situated slightly higher on the slope at the experimental site than the legume treatments and soil depth was restricted to about $0.90 \mathrm{~m}$, below which clay parent material was found. Total organic carbon (measured by combustion) at the first soil sampling following termination of the grass pasture was $2 \%$ in the $0-0.15 \mathrm{~m}$ layer and $1.5 \%$ in the $0.15-0.3 \mathrm{~m}$ layer. The 3 legume treatments were located slightly lower on the slope where the soil depth varied between 0.9 and $1.2 \mathrm{~m}$. On the legume treatments, total organic carbon at the first soil sampling was $1.7 \%$ in the $0-0.15 \mathrm{~m}$ layer and $1.4 \%$ in the $0.15-0.3 \mathrm{~m}$ layer.

Soil was characterised for plant-available water capacity (PAWC) following the procedures of Dalgliesh and Foale (1998). The drained upper limit (DUL, $392 \mathrm{~mm}$ at $0-0.9 \mathrm{~m}$ ) was determined by wetting the soil to saturation, allowing drainage to take place over 2-3 weeks, and determining soil moisture content (Table 1). The crop lower limit (CLL, $221 \mathrm{~mm}$ ), for sorghum was determined by placing a rainout shelter over a section of the 1999-2000 sorghum crop at flowering and determining the soil water content after the crop had reached maturity. Bulk density was measured on large cores collected during the determination of CLL. PAWC in the $0-0.9 \mathrm{~m}$ profile was therefore $171 \mathrm{~mm}$.
Table 1. Soil properties of the experimental site near Mt Brambling, Brian Pastures, and the values used to specify the APSIM simulation at initialisation after the pasture phases

\begin{tabular}{|c|c|c|c|c|c|}
\hline Layer number & 1 & 2 & 3 & 4 & 5 \\
\hline Layer depth (mm) & 150 & 150 & 300 & 300 & 300 \\
\hline $\begin{array}{l}\text { Water content at air dry } \\
(\mathrm{mm} / \mathrm{mm})\end{array}$ & 0.10 & 0.23 & 0.20 & 0.20 & 0.24 \\
\hline Crop lower limit $(\mathrm{mm} / \mathrm{mm})$ & 0.24 & 0.26 & 0.24 & 0.24 & 0.28 \\
\hline $\begin{array}{l}\text { Drained upper limit } \\
(\mathrm{mm} / \mathrm{mm})\end{array}$ & 0.45 & 0.43 & 0.44 & 0.43 & 0.38 \\
\hline $\begin{array}{l}\text { Saturated watercontent }{ }^{\mathrm{A}} \\
\quad(\mathrm{mm} / \mathrm{mm})\end{array}$ & 0.48 & 0.46 & 0.47 & 0.46 & 0.41 \\
\hline Swcon ${ }^{B}$ & 0.3 & 0.3 & 0.3 & 0.3 & 0.3 \\
\hline Bulk density $\left(\mathrm{g} / \mathrm{cm}^{3}\right)$ & 1.23 & 1.29 & 1.28 & 1.30 & 1.44 \\
\hline \multicolumn{6}{|l|}{ Organic carbon $(\%)$} \\
\hline Legume & 1.7 & 1.4 & 1.0 & 0.9 & 0.5 \\
\hline Grass & 2.0 & 1.5 & 1.0 & 0.9 & 0.5 \\
\hline $\mathrm{pH}$ & 7.0 & 7.0 & 7.0 & 7.0 & 7.0 \\
\hline \multicolumn{6}{|l|}{$\mathrm{NO}_{3}-\mathrm{N}(\mu \mathrm{g} / \mathrm{g})$} \\
\hline M. daltonii & 7.6 & 3.3 & 5.2 & 5.9 & 2.0 \\
\hline V. trilobata & 5.2 & 2.2 & 2.2 & 3.4 & 2.0 \\
\hline L. purpureus & 13.3 & 10.3 & 7.8 & 2.9 & 2.0 \\
\hline Grass & 1.3 & 0.2 & 0.2 & 0.1 & 0.1 \\
\hline Finert ${ }^{\mathrm{C}}$ & 0.45 & 0.55 & 0.80 & 0.99 & 0.99 \\
\hline Fbiom $^{\mathrm{D}}$ & 0.04 & 0.02 & 0.02 & 0.01 & 0.01 \\
\hline
\end{tabular}

${ }^{\mathrm{A}}$ Saturated water content calculated from total porosity -0.05 . Total porosity $=1-$ (bulk density/particle size density assumed to be 2.65).

${ }^{\mathrm{B}}$ Swcon determines the proportion of water above the DUL that will be drained each day. The Mt Brambling soil was considered have better drainage than the swcon $=0.2$ of the Warra Vertosol soil described by Probert et al. (1998).

${ }^{\mathrm{C}}$ Finert describes the proportion of initial organic carbon assumed to be inert. Assuming that all organic $\mathrm{C}$ measured at depth is essentially inert, this quantity is assumed to remain the same at all depths.

${ }^{\mathrm{D}}$ Fbiom describes the initial biom as a proportion of non-inert C. These values are based on Probert et al. (1998).

\section{Transition from pasture to sorghum}

On 12 November 1999, following a heavy grazing by cattle, the plots previously sown to $M$. daltonii, V. trilobata, or L. purpureus or grass pasture were sprayed with a knockdown herbicide and kept free of weeds. On 7 January 2000, grain sorghum (Pioneer S75) was planted at $3.2 \mathrm{~kg} / \mathrm{ha}$ into $0.25-\mathrm{m}$ rows using a no-till planter into the pasture residues that remained on the surface. In the 3 subsequent seasons, sorghum was planted at $3.0-3.6 \mathrm{~kg} / \mathrm{ha}$ into $0.9-\mathrm{m}$ row spacings using sorghum variety Buster MR in 2000-01 and Pioneer M43 in 2001-02 and 2002-03 at the dates indicated in Table 2. In the final 2002-03 season, only the $M$. daltonii, and L. purpureus treatments were continued due to resource constraints.

Table 2. Timing of cropping operations during the 4 sorghum crops following the legume and grass pastures

\begin{tabular}{lrrrr}
\hline Season & Planting & N split 1 & N split 2 & Harvest \\
\hline 1999-2000 & $7 / 01 / 00$ & $28 / 01 / 00$ & $3 / 03 / 00$ & $18 / 04 / 00$ \\
$2000-01$ & $3 / 01 / 01$ & $9 / 02 / 01$ & $12 / 03 / 01$ & $3 / 05 / 01$ \\
$2001-02$ & $13 / 12 / 01$ & $24 / 01 / 02$ & $13 / 02 / 02$ & $22 / 04 / 02$ \\
$2002-03$ & $12 / 02 / 03$ & $7 / 03 / 03$ & $16 / 04 / 03$ & $16 / 06 / 03$ \\
\hline
\end{tabular}


Within each plot, an area 20 by $5 \mathrm{~m}$, representative of the larger plot was selected. This plot was split into 2 plots 10 by $5 \mathrm{~m}$ with one half receiving $80 \mathrm{~kg} \mathrm{~N} / \mathrm{ha}(80 \mathrm{~N})$ (applied as urea by hand to the soil surface in 2 splits at the dates indicated in Table 2) and the other half no $\mathrm{N}(0 \mathrm{~N})$. These test areas remained in the same location during all 4 sorghum crops and $\mathrm{N}$ was applied to the same plot each year.

\section{Seasonal conditions}

During the period of the field trials, annual rainfall was generally near or below the average annual rainfall of $710 \mathrm{~mm}$ (Table 3 ). The in-crop rainfall received during the 1999-2000 sorghum crop was $138 \mathrm{~mm}$, $222 \mathrm{~mm}$ during the $2000-01$ season, $276 \mathrm{~mm}$ during the $2001-02$ season, and $232 \mathrm{~mm}$ during the $2002-03$ season.

\section{Sampling of the sorghum crops}

At physiological maturity, sorghum grain and stover were harvested for the determination of yield and $\mathrm{N}$ concentration. Two separate and centrally located 5-m rows within each plot were selected and the number of plants and grain heads were counted. The heads were cut from the plants, removed, and bagged and the remaining stover was cut at ground level and removed for weighing. Stover was dried in a forced-air dehydrator at $80^{\circ} \mathrm{C}$ for $48 \mathrm{~h}$ and weighed to determine dry matter. The sorghum heads were dried, threshed to remove grain, and weighed. Grain yield is expressed on an oven-dry basis. The straw and husk material from the threshed heads was added to the stover weights.

Total $\mathrm{N}$ content of the grain and stover samples were determined by colourimetric analysis (Crooke and Simpson 1971) after Kjeldahl digestion (Bremner 1965). Protein concentration of sorghum grain was calculated as $\% \mathrm{~N}$ in grain $\times 6.25$.

Following each sorghum harvest, regrowth was sprayed with a knockdown herbicide, and after the withholding period, cattle grazed the plant residues.

\section{Soil sampling for water and mineral $N$}

Soil samples were taken in each test plot prior to planting and following harvest of the 4 sorghum crops and analysed for nitrate- $\mathrm{N}$ and water content. All samples were taken using a vehicle-mounted hydraulic soil sampler with cores to $0.9 \mathrm{~m}$ being sampled and partitioned into $0-0.15$, $0.15-0.3,0.3-0.6$, and $0.6-0.9 \mathrm{~m}$ depth increments for analysis. Soil nitrate-N was determined using the method of Keeny and Nelson (1982) described in Raymond and Higginson (1992). Soil water content was determined after drying the soil samples at $100^{\circ} \mathrm{C}$.

In-crop mineralisation (ICM) was calculated using Eqn 1 for the $0 \mathrm{~N}$ treatments as suggested by Armstrong et al. (1999b):

$$
\operatorname{ICM}(\mathrm{kg} \mathrm{N} / \mathrm{ha})=\left(\mathrm{C}_{\mathrm{N}} \times 1.3\right)+\text { Nitrate }_{\mathrm{AH}}-\text { Nitrate }_{\text {Sow }}
$$

where $\mathrm{C}_{\mathrm{N}}$ is the above-ground $\mathrm{N}$ uptake by sorghum, and Nitrate $_{\mathrm{AH}}$ and Nitrate $_{\text {Sow }}$ is the soil nitrate $\mathrm{N}$ measured to $0.9 \mathrm{~m}$ depth after harvest and before sowing of each sorghum crop, respectively. According to McNeill et al. (1998) a correction factor of 1.3 applied to the above-ground material will account for the likely proportion of plant $\mathrm{N}$ located below ground. The ICM calculation assumes no loss of N (via such mechanisms as volatilisation, denitrification, and leaching).

\section{APSIM simulation}

APSIM Version 3.6 was used to simulate the soil $\mathrm{N}$ and water dynamics and sorghum growth from the time of pasture termination until harvest of the fourth sorghum crop in June 2003. The M. daltonii, V. trilobata, and $L$. purpureus treatments were initialised using the parameters outlined in Table 1 for a soil profile of $1.2 \mathrm{~m}$ depth. Simulations of the grass treatment used the parameters in Table 1 but for a soil profile of $0.9 \mathrm{~m}$. Only the unfertilised $(0 \mathrm{~N})$ treatments were simulated. Daily climatic records (maximum and minimum temperatures, rainfall, solar radiation) for the duration of the experiment and for the period 1954-2004 were obtained from a weather station situated $<500 \mathrm{~m}$ from the experimental site.

The simulation was initialised on 12 November 1999, corresponding with the time when the pastures were terminated in the field. In the M. daltonii, V. trilobata, and L. purpureus treatments, 4866, 2268, and $2398 \mathrm{~kg} / \mathrm{ha}$ of legume residues, respectively, were added to the soil residue pool (fresh organic matter, FOM in APSIM). Dimes et al. 1996 found that under a Stylosanthes hamata $\mathrm{cv}$. Hamata legume pasture, root biomass was $1829 \mathrm{~kg} /$ ha with a $\mathrm{C}: \mathrm{N}$ of $23-25$. We use this as the basis for assuming that $2000 \mathrm{~kg}$ of legume root residues at a $\mathrm{C}: \mathrm{N}$ of 20 was added to the soil residue pool at initialisation of the model run.

In the grass treatments, $4427 \mathrm{~kg} / \mathrm{ha}$ of surface residue was present $(\mathrm{C}: \mathrm{N} 40)$ and added to the soil residue pool with an addition of $10000 \mathrm{~kg} /$ ha of root material $(\mathrm{C}: \mathrm{N} 50)$. The $\mathrm{C}: \mathrm{N}$ ratios of the added residues for the grass pastures were obtained from the studies of Robertson et al. (1994) for P. maximum and root residue amount was assumed to be similar to that reported in Dimes et al. (1996). Soil nitrate-N and water was initialised to the measured values obtained at the first sampling (Tables 1 and 4). Soil ammonium-N was assumed to be negligible as suggested by Myers (1975).

From the point of initialisation, simulations were run continuously with no further resets. All management parameters in the model (i.e. time of sowing, sorghum variety, plant population) mimicked field management (Table 2). The model determined harvest on the basis of the simulated crop reaching physiological maturity. Weeds were not included in the model simulations and it was assumed that the low weed populations in the field during the sorghum crops did not limit growth. In the simulations, sorghum residue was managed by removing $60 \%$ of the residue at 14 days after harvest and a further $50 \%$ of the remainder at 30 days after harvest. This was to mimic the crash grazing of residues by cattle in the field. No attempt was made to simulate the effect of faecal return on soil organic matter and soil $\mathrm{N}$.

\section{Long-term simulations}

To analyse the long-term effect of seasonal conditions on unfertilised sorghum production in the first season following the termination of

Table 3. Monthly rainfall (mm) received at Brian Pastures Research Station from July 1998 to June 2003 and the monthly and yearly long-term average (1963-2002)

\begin{tabular}{lrrrrrrrrrrrrr}
\hline & July & Aug. & Sep. & Oct. & Nov. & Dec. & Jan. & Feb. & Mar. & Apr. & May & June & Year \\
\hline $1998-99$ & 22 & 26 & 119 & 21 & 107 & 90 & 35 & 51 & 49 & 5 & 30 & 37 & 592 \\
$1999-2000$ & 84 & 14 & 33 & 107 & 118 & 53 & 78 & 61 & 27 & 33 & 27 & 26 & 661 \\
$2000-01$ & 5 & 3 & 0 & 171 & 70 & 66 & 7 & 138 & 120 & 32 & 46 & 1 & 659 \\
$2001-02$ & 46 & 1 & 38 & 33 & 155 & 52 & 18 & 164 & 60 & 5 & 49 & 70 & 691 \\
$2002-03$ & 0 & 91 & 0 & 64 & 24 & 58 & 0 & 113 & 63 & 61 & 43 & 10 & 527 \\
Average & 35 & 29 & 29 & 61 & 70 & 105 & 110 & 94 & 71 & 37 & 40 & 29 & 710 \\
\hline
\end{tabular}


a pasture, APSIM was initialised with the soil water and mineral $\mathrm{N}$ conditions that were measured following each of the pasture treatments. The inputs of pasture residues and root materials were also initialised as described in the previous section. Simulations were then run from 1954 to 2004 using the long-term weather data collected at the station during this period. Each year, the sorghum crop was sown between 15 November and 15 January when at least $30 \mathrm{~mm}$ of rain was received over 5 consecutive days. As all soil conditions were reset to the same parameters each season, the effect of climate on sorghum grain production was predicted following each pasture treatment. It was assumed that all treatments (including the grass treatment) had a soil depth of $1.2 \mathrm{~m}$ and therefore a PAWC of $202 \mathrm{~mm}$. An additional simulation of the grass treatment was done with the soil water being reset to the DUL before sowing each year to investigate sorghum growth without the bias of lower soil water in that treatment.

\section{Statistical analysis}

The experiment was a split-plot design with pasture type (M. daltonii, V. trilobata, L. purpureus, or grass pasture) as main plots (replicated twice) which were split into 2 fertiliser rates $(0 \mathrm{~N}, 80 \mathrm{~N})$ during the sorghum phase. For the data generated during the seasons 1999-2000, 2000-01, and 2001-02, comparison of the 4 pasture treatments is against the residual (pasture type $\times$ replicate). The sub plots and interactions were tested against the residual term (pasture type $\times$ replicate $\times$ year $\times$ fertiliser). In the final year (2002-03), only the main plot treatments $M$. daltonii and L. purpureus continued, so data analysis was confined to within that year. Where there was significance, the least significant difference (1.s.d.) at $P=0.05$ was used to test for mean separation. All data were tested for the assumption of common variance and transformed if necessary. The soil nitrate content data in Table 8 were statistically analysed after $\log$ transformation to achieve normal distribution.

To assess the goodness of fit of the sorghum yield, soil nitrate, and water simulations, the root mean square error (RMSE) between predicted and observed data was calculated as:

$$
\operatorname{RMSE}=\left[\left(\Sigma(\mathrm{O}-\mathrm{P})^{2} / n\right)\right]^{0.5}
$$

where $\mathrm{O}$ and $\mathrm{P}$ are the paired observed and predicted data and $n$ is the number of observations.

\section{Results}

\section{Soil water content at sorghum sowing}

The soil water measurements taken at pre-planting of sorghum showed no significant difference between the treatments in any of the years (Table 4). These measurements, expressed as a percentage of the PAWC, were generally $>50 \%$ with the driest soil profiles being measured at the beginning of the trial soon after pasture termination. Despite no statistical difference between the treatments, the grass treatments were

Table 4. Total soil water $(\mathrm{mm})$ in the $0-0.9 \mathrm{~m}$ profile prior to the sowing of sorghum

This is shown in parentheses as a \% of PAWC $($ PAWC $=171 \mathrm{~mm})$

\begin{tabular}{lcccc}
\hline & $1999-2000$ & $2000-01$ & $2001-02$ & $2002-03$ \\
\hline M. daltonii & $293(42)$ & $317(65)$ & $316(56)$ & $283(36)$ \\
V. trilobata & $246(15)$ & $302(47)$ & $278(33)$ & - \\
L. purpureus & $283(36)$ & $330(64)$ & $329(63)$ & $288(40)$ \\
Grass & $236(9)$ & $263(25)$ & $262(24)$ & - \\
\hline
\end{tabular}

consistently drier than the treatments following the legume pastures in every year (range 10-57, 39-67, and 16-67 mm less soil water in years 1, 2, and 3, respectively). Since soil depth under the legume treatments was up to $0.30 \mathrm{~m}$ deeper than the grass treatments, PAWC was potentially up to $28 \mathrm{~mm}$ greater.

\section{Sorghum production}

In the first sorghum crop after the pasture phase, grain and stover growth following the L. purpureus treatments were significantly higher than the $M$. daltonii, V. trilobata, and grass treatments with no difference found between the last 3 treatments (Tables 5 and 6). In the second sorghum crop, the L. purpureus treatments continued to outyield all other treatments with an exceptional grain yield of $5254 \mathrm{~kg} /$ ha. The $V$. trilobata treatment also outyielded the grass treatment. By the third sorghum crop, grain and stover production was similar for all treatments. In 2002-03, only the M. daltonii and L. purpureus treatments continued and there were no differences in grain yield and stover measured.

No significant yield responses to the $80 \mathrm{~N}$ fertiliser treatments were measured in any of the seasons and the data in Table 5 are therefore an average of the 0 and $80 \mathrm{~kg} / \mathrm{ha} \mathrm{N}$ treatments. This lack of response to $\mathrm{N}$ in the grass treatments was despite the low and obviously limiting

Table 5. Grain production (average of the $0 \mathrm{~N}$ and $80 \mathrm{~N}$ treatments) of the 4 sorghum crops following a grass pasture or 2 year legume leys (kg/ha)

Data for 2002-03 analysed within that year and no significant difference between the means found

\begin{tabular}{lcccc}
\hline & 1999-2000 & 2000-01 & 2001-02 & 2002-03 \\
\hline M. daltonii & 2825 & 3056 & 2825 & 3154 \\
V. trilobata & 2401 & 3727 & 2492 & - \\
L. purpureus & 4098 & 5254 & 2637 & 3165 \\
Grass & 1858 & 1776 & 3455 & - \\
$\begin{array}{l}\text { 1.s.d. }(P \leq 0.05) \\
\quad(\text { pasture treatment } \times \text { year) }\end{array}$ & 1434 & & n.s. \\
\hline
\end{tabular}

Table 6. Stubble production (average of the $0 \mathrm{~N}$ and $80 \mathrm{~N}$ treatments) of the 4 sorghum crops following a grass pasture or 2 year legume leys $(\mathrm{kg} / \mathrm{ha})$

Data for 2002-03 analysed within that year and no significant difference between the means found

\begin{tabular}{lcrcc}
\hline & $1999-2000$ & $2000-01$ & $2001-02$ & $2002-03$ \\
\hline M. daltonii & 3409 & 6614 & 5755 & 2755 \\
V. trilobata & 3781 & 7560 & 4128 & - \\
L. purpureus & 6309 & 11300 & 5039 & 2654 \\
Grass & 2619 & 4402 & 5454 & - \\
$\begin{array}{l}\text { 1.s.d. }(P \leq 0.05) \\
\quad(\text { pasture treatment } \times \text { year) }\end{array}$ & 2311 & & n.s. \\
\hline
\end{tabular}


nitrate concentrations measured at sowing described in the following sections.

\section{Grain protein}

Although sorghum yield showed no response to $\mathrm{N}$ fertiliser, average grain protein was consistently higher in the $80 \mathrm{~N}$ treatments, being significantly $(P<0.05)$ so in the second and fourth sorghum crops (Table 7). Total $\mathrm{N}$ uptake in the plant shoots also increased in the $80 \mathrm{~N}$ treatments (data not shown).

\section{Dynamics of nitrate during the sorghum phase}

\section{Pre-sowing sampling}

Soil nitrate measured after the termination of the grass pasture treatment was $4 \mathrm{~kg} \mathrm{~N} / \mathrm{ha}$ compared with significantly higher values of $35-86 \mathrm{~kg} \mathrm{~N} / \mathrm{ha}$ of following the legume leys (Table 8). During the first 2 years of the trial, soil nitrate remained in the order L. purpureus $>M$. daltonii $>V$. trilobata $>$ grass. By the third season, soil nitrate in the grass treatment had increased to a mean of $43 \mathrm{~kg} / \mathrm{ha}$, which was higher than the V. trilobata treatment. Despite no significant effect of fertiliser treatment, soil nitrate in the $0 \mathrm{~N}$ fertiliser treatments of the grass plots was 15 (see Fig. $4 b$ ) compared with $72 \mathrm{~kg} / \mathrm{ha}$ on the $80 \mathrm{~N}$ treatments; large variation in replicates and between years made this effect non significant.

\section{Post harvest samplings}

The main effects of previous pasture type, fertiliser application, and year were found to be significant; however,

Table 7. Sorghum grain protein $(\%)$ in response to 0 or $80 \mathrm{~kg} / \mathrm{ha}$ of $\mathbf{N}$ fertiliser applied to each sorghum crop

\begin{tabular}{lcccc}
\hline N rate $(\mathrm{kg} / \mathrm{ha})$ & $1999-2000$ & $2000-01$ & $2001-02$ & $2002-03$ \\
\hline 0 & 11.2 & 8.9 & 10.6 & 6.5 \\
80 & 11.9 & 11.0 & 12.2 & 11.0 \\
1.s.d. $(P \leq 0.05)$ & n.s. & 1.1 & n.s. & 1.5 \\
\hline
\end{tabular}

Table 8. Soil nitrate $\mathrm{N}(\mathrm{kg} / \mathrm{ha})$ in the $0-0.9 \mathrm{~m}$ profile prior to the sowing of sorghum

Data in all years are the mean of the 0 and $80 \mathrm{~N}$ treatments that were not significantly different (analysis of variance performed on raw data transformed using a log function to achieve normal distribution). Data for 2002-03 analysed within that year and no significant difference between the means found

\begin{tabular}{lcccc}
\hline & 1999-2000 & 2000-01 & 2001-02 & 2002-03 \\
\hline M. daltonii & 63 & 97 & 99 & 64 \\
V. trilobata & 35 & 58 & 33 & - \\
L. purpureus & 86 & 98 & 88 & 56 \\
Grass & 2 & 12 & 43 & - \\
$\begin{array}{l}\text { 1.s.d. }(P \leq 0.05) \\
\quad(\text { pasture treatment } \times \text { year })\end{array}$ & 2 & & n.s. \\
\hline
\end{tabular}

there were no significant treatment interactions. Averaged over the 3 years, soil nitrate increased at harvest from $18 \mathrm{~kg} / \mathrm{ha}$ in the $0 \mathrm{~N}$ treatment to $59 \mathrm{~kg} / \mathrm{ha}$ in the $80 \mathrm{~N}$ treatments. Averaged over the pasture treatments, soil nitrate decreased with each harvest from $57 \mathrm{~kg} / \mathrm{h}$ a in year 1 to $36 \mathrm{~kg} / \mathrm{ha}$ in year 2 and $22 \mathrm{~kg} / \mathrm{ha}$ in year 3 . In the treatment continued into the fourth year, soil nitrate declined further to $19 \mathrm{~kg} / \mathrm{ha}$. Averaged over fertiliser treatments and year, post harvest soil nitrate remained lowest in the grass treatments $(17 \mathrm{~kg} / \mathrm{ha})$, compared with 65,46 , and $25 \mathrm{~kg} / \mathrm{ha}$ in the M. daltonii, L. purpureus, and V. trilobata treatments, respectively.

Following the first harvest, high concentrations of nitrate were found in the $0-0.15 \mathrm{~m}$ soil layers of all $80 \mathrm{~N}$ treatments (average of $28 \mathrm{mg} / \mathrm{kg}$ in the $80 \mathrm{~N}$ treatments compared with $7 \mathrm{mg} / \mathrm{kg}$ in the $0 \mathrm{~N}$ treatments). This indicates that most of the surface-applied fertiliser had not been leached into the root zone and therefore was not available to the crop; this $\mathrm{N}$ was not detected at sowing in the following season. As mentioned in the section on sorghum production, the ineffective application of $80 \mathrm{~N}$ did not result increased yield in the grass treatments as expected.

The calculated ICM of soil $\mathrm{N}$ showed no significant differences between treatments in any of the years (Table 9) The highest average ICM was measured in the second crop (mean $109 \mathrm{~kg} / \mathrm{ha} \mathrm{N}$ ) and this declined to a mean of $41 \mathrm{~kg} \mathrm{~N} / \mathrm{ha}$ by the fourth crop.

\section{Simulation of sorghum growth, $N$ dynamics, and soil water using APSIM}

The simulation of the grain yield, soil nitrate, and soil water for the unfertilised treatments of the sorghum phase of the experiment was undertaken from the point of pasture termination (12 Nov. 1999) until the final soil sampling (16 June 2003) for the 3 legume systems and the grass pasture system (Figs 1-4). Observed data for the 4 sorghum crops are presented along with the standard error of the mean (s.e.m.) for each data point. These data are for the individual treatments and may therefore differ from the means of treatments presented in Tables 4, 5, 8, and 9.

\section{Grain yield}

There is considerable variation in the measured mean yields of sorghum for the M. daltonii treatment in the second

Table 9. In-crop mineralisation (ICM) of $\mathrm{N}(\mathrm{kg} / \mathrm{ha})$ calculated using Eqn 1 for each the unfertilised sorghum crops following 4 pasture histories

\begin{tabular}{lrrcc}
\hline & $1999-2000$ & $2000-01$ & $2001-02$ & $2002-03$ \\
\hline M. daltonii & 71 & 104 & 78 & 33 \\
V. trilobata & 74 & 84 & 45 & - \\
L. purpureus & 127 & 134 & 33 & 49 \\
Grass & 37 & 113 & 83 & - \\
Mean & 77 & 109 & 60 & 41 \\
\hline
\end{tabular}



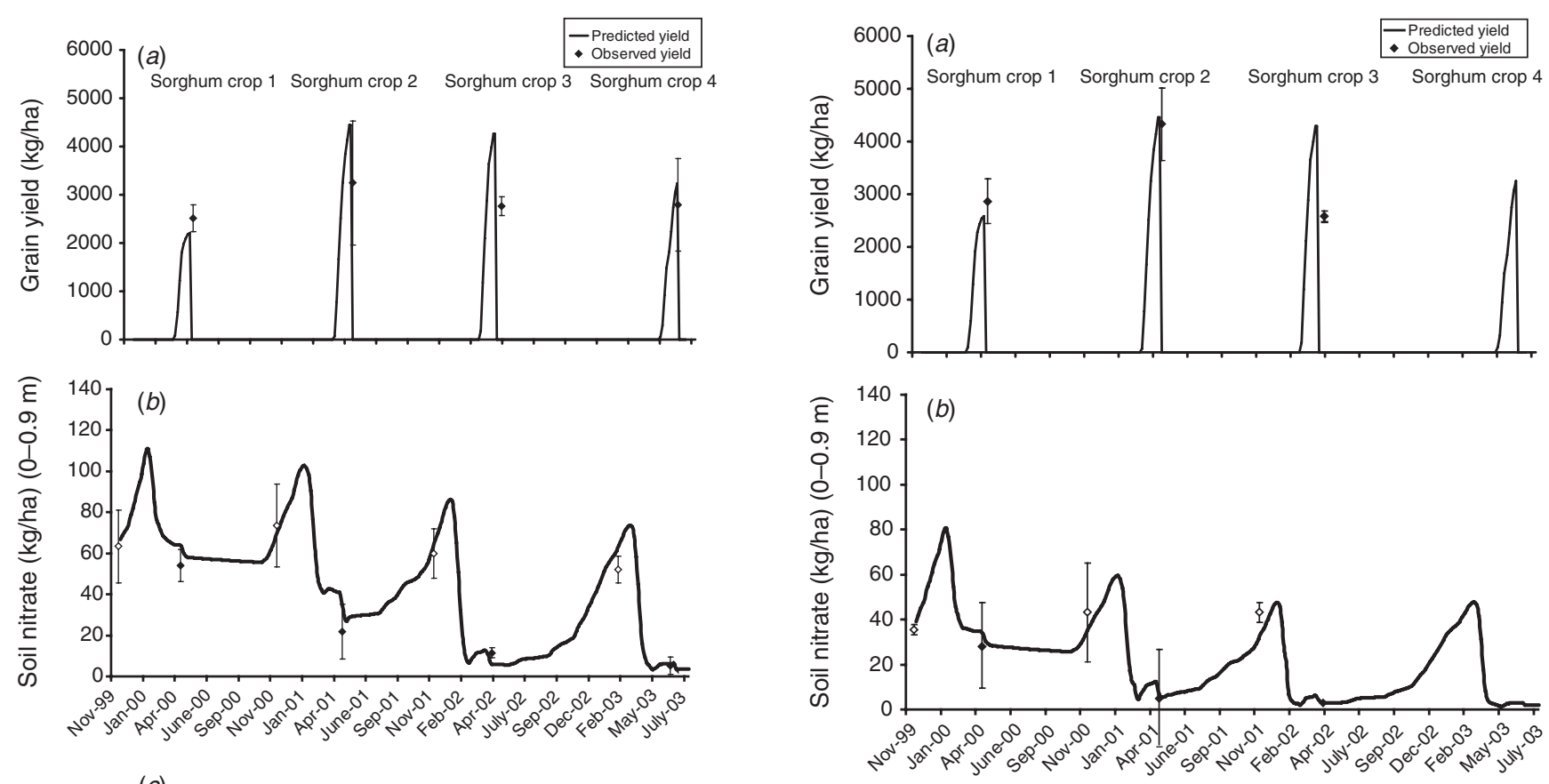

(c)

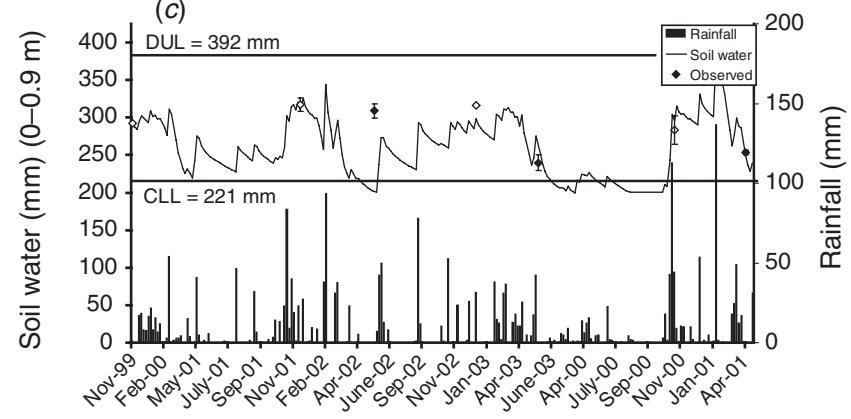

Fig. 1. (a) Sorghum grain yield, (b) soil nitrate $\mathrm{N}$ content $(0-0.9 \mathrm{~m})$, and $(c)$ soil water $(0-0.9 \mathrm{~m})$ and cumulative rainfall (over 5 days) during a cropping phase $(0 \mathrm{~N})$ that was preceded by 2 years of $M$. daltonii pasture.

and fourth crops (Fig. 1a), in the L. purpureus treatment in the first and third crops (Fig. 3a), and in the grass treatment for the third crop (Fig. 4a). Simulated sorghum yields are overestimated in the third crop for these 3 treatments. The prediction of grain yields following the V. trilobata (Fig. 2a) was close in the 3 measured seasons. The RSME for the pooled dataset (predicted and observed yields for the 4 treatments) was $1065 \mathrm{~kg} / \mathrm{ha}$, which represents $35 \%$ of the mean. The predicted $v$. observed data together with the $1: 1$ line are plotted in Fig. $5 a$.

Simulation of the sorghum crops grown after the grass treatment shows a general increase in grain yield (in agreement with the observed data) with the increasingly available mineral $\mathrm{N}$ suggested by the model (not in agreement with the observed data). By the third crop, predicted grain yield exceeds the measured by $>1 \mathrm{t} / \mathrm{ha}$, which is probably due to the overestimation of soil nitrate at sowing (Fig. $4 b$ ).
Fig. 2. (a) Sorghum grain yield and $(b)$ soil nitrate-N content $(0-0.9 \mathrm{~m})$ during a cropping phase $(0 \mathrm{~N})$ that was preceded by 2 years of $V$. trilobata pasture.

For all crops, the simulated maturity date is generally within 7 days of the field harvest date, with the exception of the third crop where maturity was 16 days earlier than the field harvest. This discrepancy is of little importance, as the field date of harvest may be later than physiological maturity.

\section{Soil nitrate dynamics in the legume treatments}

With the exception of the year 1 harvest nitrate value following the lablab pasture (Fig. $3 b$ ), each of the measured values of nitrate at sowing and harvest are in close agreement with the simulated data for the 3 legume treatments (Figs $1 b, 2 b$, and $3 b$ ). In the legume treatments there was a general decline in the amount of nitrate in the profile after harvest with each succeeding sorghum crop. This is in close agreement with the $0 \mathrm{~N}$ treatments of the field data. $\mathrm{N}$ accumulation between crops is significant and varies between 26 and $43 \mathrm{~kg} \mathrm{~N} / \mathrm{ha}$. When crop $\mathrm{N}$ uptake exceeds soil $\mathrm{N}$ mineralisation rate, the soil nitrate content declines until such a time that crop $\mathrm{N}$ demand is reduced and the soil water and temperatures are adequate for soil $\mathrm{N}$ mineralisation.

\section{Soil nitrate dynamics in the grass treatment}

After the termination of the grass pasture, soil nitrate remains very low $(<8 \mathrm{~kg} / \mathrm{haN})$ until after the presowing measurement in the second sorghum crop. The nitrate simulation in Fig. $4 b$ indicates that there is some 

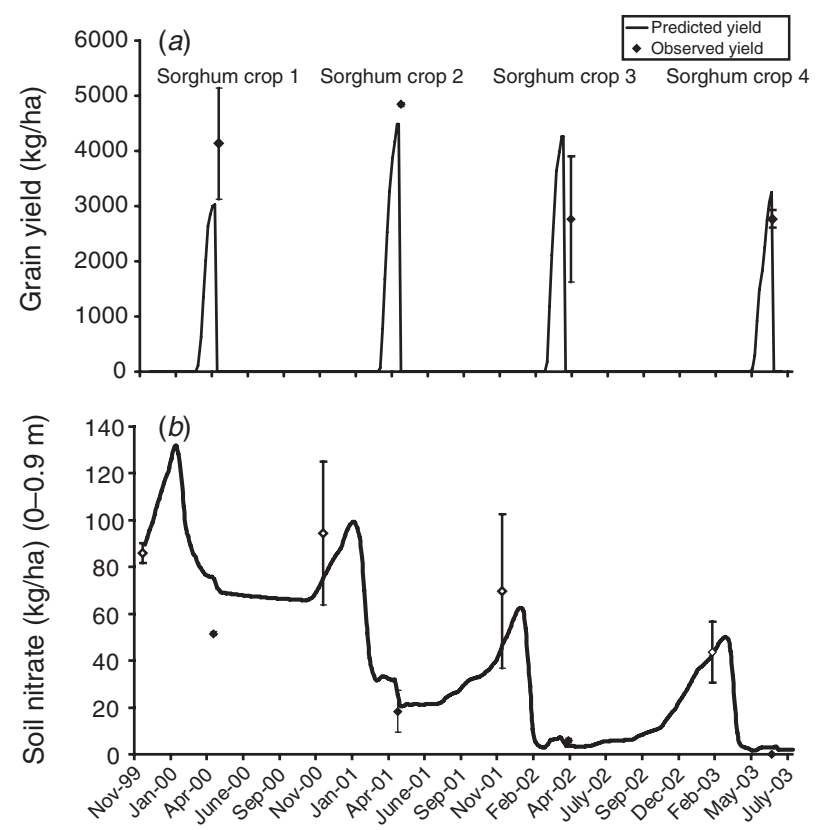

(c)

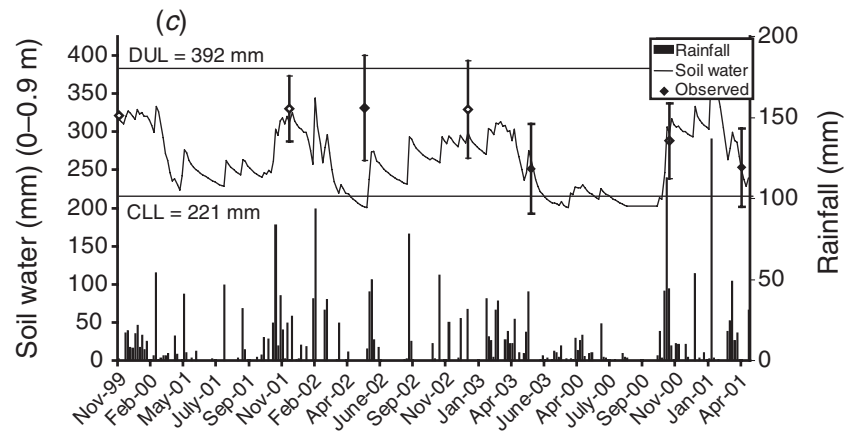

Fig. 3. (a) Sorghum grain yield, (b) soil nitrate $\mathrm{N}$ content $(0-0.9 \mathrm{~m})$, and $(c)$ soil water $(0-0.9 \mathrm{~m})$ and cumulative rainfall (over 5 days) during a cropping phase $(0 \mathrm{~N})$ that was preceded by 2 years of $L$. purpureus pasture.

accumulation in sorghum crops 2,3 , and 4 . The simulated soil nitrate accumulation around sowing time of the third crop exceeds the measured value by almost $65 \mathrm{~kg} \mathrm{~N} / \mathrm{ha}$. This large discrepancy may be due to the model mineralising $\mathrm{N}$ in this treatment too rapidly - substantial $\mathrm{N}$ was mineralised during the crop (ICM of nitrate, $83 \mathrm{~kg} / \mathrm{ha}$, Table 9), so a small error in the rate of mineralisation may account for some of this overestimation.

Figure $5 b$ shows the generally good agreement between the predicted and observed soil nitrate data; the outlining data points are from the grass treatments. The RSME of the soil nitrate dataset calculated using the predicted and observed data for the legume treatments only was $11 \mathrm{~kg} / \mathrm{ha}$ of nitrate, representing $28 \%$ of the mean. The RSME increased to $14 \mathrm{~kg} / \mathrm{ha}$ with the inclusion of nitrate data from the grass treatment, representing $44 \%$ of the mean (Fig. 5b).
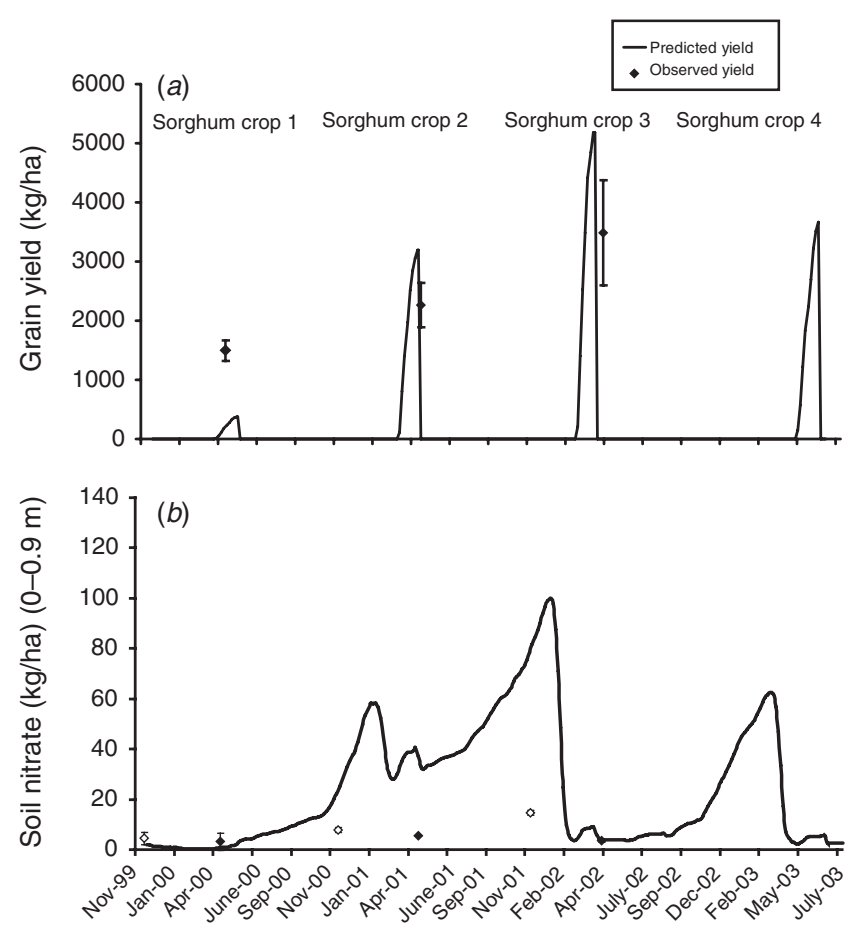

Fig. 4. (a) Sorghum grain yield and (b) soil nitrate $\mathrm{N}$ content $(0-0.9 \mathrm{~m})$ during a cropping phase $(0 \mathrm{~N})$ that was preceded by 2 years of grass pasture. In each figure, the solid line represents the simulated value. The open points are the measured soil nitrate values prior to sorghum sowing and the closed points are the measured soil nitrate values after harvest. Vertical bars represent the s.e.m. of the measured data where bars are absent, the s.e.m. is smaller than the symbol.

\section{Soil water}

Soil water content $(0-0.9 \mathrm{~m})$ was also simulated for the 0N treatments from initialisation in November 1999 until July 2003. These results are displayed for the $M$. daltonii and $L$. purpureus treatments where a full set of measured field values was available (Figs $1 c$ and $3 c$ ). The simulated soil water remains within the bounds of the DUL and CLL (indicated on the figures by lines), except after harvest where air-drying of the surface soil layers may reduce the soil water content to below CLL. Increases in the predicted total soil water correspond well with the rainfall events indicated in these figures.

The simulation of soil water resulted in generally good agreement with the measured points at sowing with most predictions within the error of the measured points. These error values were very substantial for the $L$. purpureus treatments (Fig. 3c). Soil water balance parameters such as runoff, evaporation, and drainage appear to be well simulated as indicated by the good correlations at sowing between observed and simulated soil water after the fallow.

At sorghum harvest, simulated water extraction was consistently overestimated relative to the observed data (Figs $1 c$ and $3 c$ ). While the simulation only allowed water 
extraction to $1.2 \mathrm{~m}$, PAWC below this depth was low; for example, PAWC in the $1.2-1.5$ depth was $3 \mathrm{~mm}$ (data not shown), so it is unlikely that the sorghum plots accessed
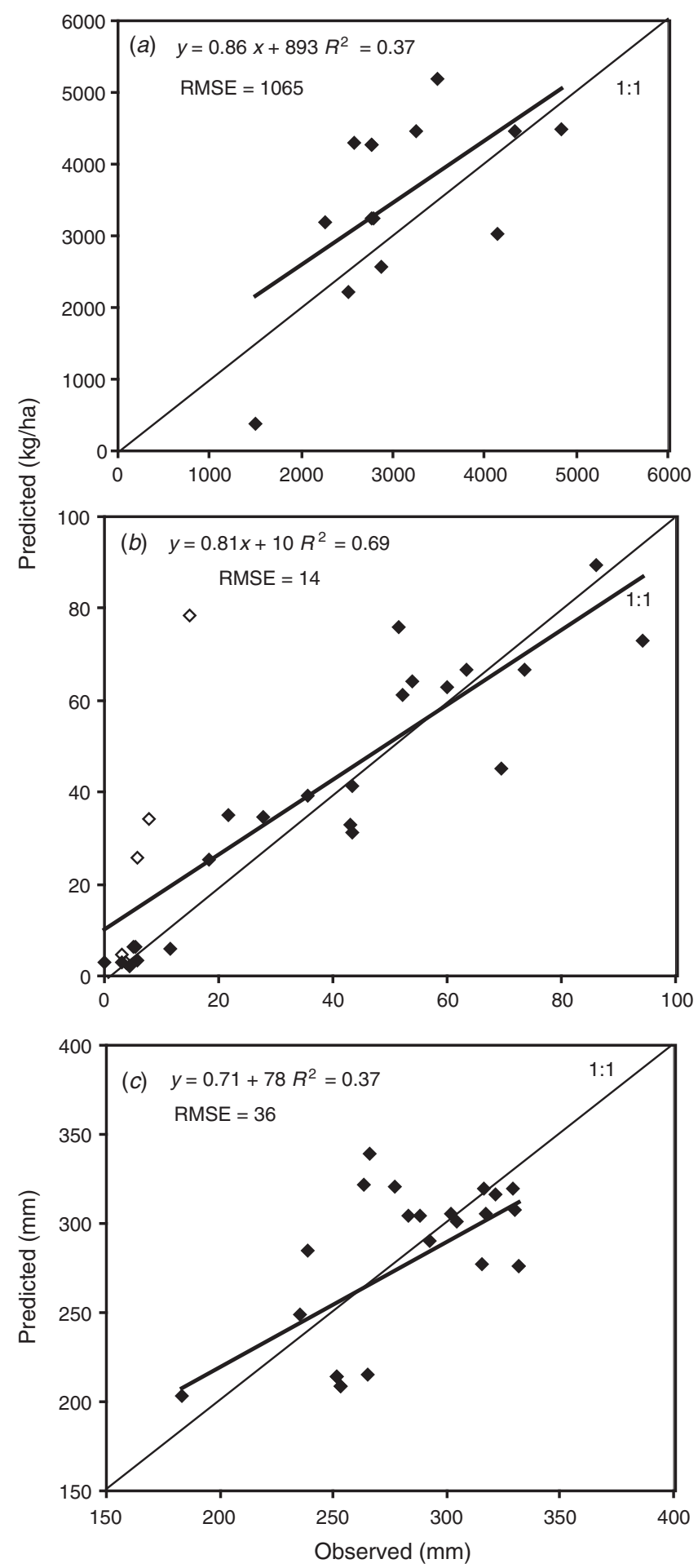

Fig. 5. Predicted $v$. observed ( $a$ ) grain yield of sorghum, $(b)$ soil nitrate (open points are the values of the grass treatments), and (c) soil water of the $0 \mathrm{~N}$ treatments. much water below $1.2 \mathrm{~m}$. This discrepancy in the simulation may therefore indicate excessive water use in this version of the sorghum model. RMSE of the predicted and observed data was $36 \mathrm{~mm}$, representing $12 \%$ of the mean. The predicted $v$. observed data are plotted with the $1: 1$ line in Fig. $5 c$.

\section{Long-term simulations}

Simulation of the first sorghum crop following a legume or grass ley was conducted by resetting soil water and soil nitrate to the same values that were measured in 1999 after 2 years of the pasture treatments and allowing for the additions of plant residues and root material for each pasture system. This allowed the effect of seasonal conditions experienced in each year from 1954 to 2004 to determine the sorghum growth (Fig. 6). Following a grass pasture, grain production did not exceed $3000 \mathrm{~kg} / \mathrm{ha}$, and approximately $60 \%$ of the time, grain production was $1000-2000 \mathrm{~kg} / \mathrm{ha}$. Initialising the model with the soil nitrate and water data measured after any of the 2-year legume leys, grain production was found to range from 3000 to $4500 \mathrm{~kg} / \mathrm{ha}$ in $>75 \%$ of the seasons between 1954 and 2004. By simulating the grass treatment with the soil water content reset to the DUL each season, the bias of low soil water following a grass pasture was removed. The 'grass DUL' line on the cumulative distribution function does increase the average by $362 \mathrm{~kg} / \mathrm{ha}$, but grain production continues to be limited by the low starting soil $\mathrm{N}$ concentrations following the grass pasture.

\section{Discussion}

This paper contrasts 2 grain and graze systems; one is a legume based rotational pasture-crop system, which is highly

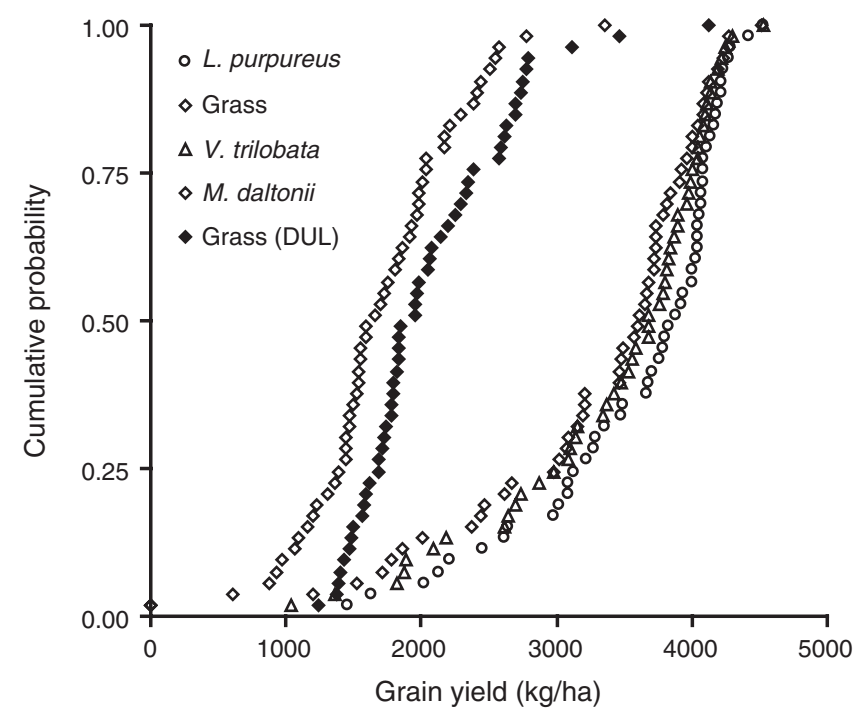

Fig. 6. Cumulative probability of sorghum grain yield (with no added fertiliser N) in the seasons from 1954 to 2003 using the soil water and nitrogen starting measured in the field after 2 seasons of $M$. daltonii, L. purpureus, V. trilobata, or a grass pasture (grass DUL). 
productive in terms of both animal and crop production. This productivity is driven largely by biological $\mathrm{N}$ fixation resulting in legume residues of high feed value (high digestibility and protein) and, via the cycling of $\mathrm{N}$ in faeces and decomposing plant residues, high soil N. The other system, a perennial grass based pasture, was highly productive in terms of beef liveweight gain (Clem 2004; Whitbread and Clem 2004), but upon termination of the pasture phase, low soil mineral $\mathrm{N}$ limited sorghum production for 2 seasons (Table 5).

\section{$N$ dynamics}

High levels of soil nitrate $\mathrm{N}$ were measured in the legume treatments within 12 days of the termination to the legume pastures (Table 8). This indicates that the rapid decomposition of the legume residues, the recycling of $\mathrm{N}$ through the previous seasons of legume pasture growth, and animal grazing and defecation have enabled the buildup of mineral N. Whitbread et al. (2005) also found that soil nitrate levels increased following the termination of grazed tropical legumes such as L. purpureus $\mathrm{cv}$. Endurance and Macroptilium bracteatum (burgundy bean) to 101 and $59 \mathrm{~kg} / \mathrm{ha}(0-1.5 \mathrm{~m})$, respectively, compared with only $46 \mathrm{~kg} / \mathrm{ha}$ under a continuous wheat system. The studies by Armstrong et al. (1999b) on Vertosol soils in Central Queensland showed that 1-3 seasons of legumes (mungbean, siratro, lucerne, lablab, and desmanthus) progressively increased soil nitrate levels to $47-82 \mathrm{~kg} / \mathrm{ha}$ compared with $<25 \mathrm{~kg} / \mathrm{ha}$ in a continuous sorghum system.

In contrast to the legume systems, soil nitrate $\mathrm{N}$ remained very low in the first 2 seasons following termination of the grass system, and only in the third year did soil nitrate $\mathrm{N}$ reach concentrations comparable to the legume systems (Table 8). During the grass pasture, there were no $\mathrm{N}$ inputs and $\mathrm{N}$ in the system would be recycled largely through grazing and faecal return and residue turnover. $\mathrm{N}$ deficiency in grassland pastures has been well documented in the Brigalow landscapes of Central Queensland by Robertson et al. (1993a, 1992b, 1994). Robertson et al. (1993a) found that up to $20 \mathrm{t} / \mathrm{ha}$ of surface litter and root residues of high $\mathrm{C}: \mathrm{N}$ ratio (40-50) accumulated under these pastures. Using incubation techniques, they found that pasture soil respired more $\mathrm{CO}_{2}$ and mineralised less $\mathrm{N}$ than cultivated soils. Since the C:N ratio of pasture residues is high $(>40)$, immobilisation of mineral $\mathrm{N}$ occurs.

In the unfertilised treatments that followed the grass pasture, soil nitrate- $\mathrm{N}$ content measured at pre-sowing remained low (Fig. 4b). ICM of N in 2000-01 and 2001-02 was, however, comparable to the legume treatments (Table 9) and does indicate that $\mathrm{N}$ is becoming available over time. Substantial mineralisation could be expected from the high soil $\mathrm{C}$ concentrations measured in the grass treatments (Table 1).

\section{Sorghum grain production}

In the system described in this study, sorghum was established using a no-till planter. This results in minimal soil disturbance and slower decomposition of the surface and buried plant residues than under conventional tillage. While Blair and Crocker (2000) recommended that no-till practices combined with the residue returns from primary and rotational crops could potentially increase soil $\mathrm{C}$ concentration and soil structural stability, a no-till system could exacerbate $\mathrm{N}$ deficiency in a system where grass pasture is converted to crop production.

High-yielding sorghum crops were grown after all legume pastures over the 4 seasons (Table 5). The exceptional grain yield of $5254 \mathrm{~kg} / \mathrm{ha}$ achieved in the L. purpureus treatment in the second sorghum crop corresponded with high starting soil nitrogen $(98 \mathrm{~kg} / \mathrm{haN})$ a $65 \%$ full profile of water and good in-crop rainfall $(222 \mathrm{~mm})$. Using APSIM to simulate the soil-plant system, the effect of water and $\mathrm{N}$ stress on leaf expansion and phenology can be derived. Interestingly for this high-yielding L. purpureus crop, there was no stress at any stage during crop growth, indicating that water or $\mathrm{N} \mathrm{did}$ not limit crop growth.

Utilising the APSIM-derived stress indices (Carberry and Abrecht 1991) to help interpret the measured data, $N$ stress was found not to limit the yield of the unfertilised or fertilised legume crops at any stage of growth during the 4 sorghum crops. In contrast, water stress generally occurred during flowering and grainfill, indicating that water was limiting crop growth. This is further supported by the measured data showing the soil water content to be at CLL near harvest in each season.

In the grass treatments, low soil $\mathrm{N}$ content at sowing of the first crop did severely limit crop growth. As explained previously in the Results, the application of $80 \mathrm{~N}$ did not ameliorate this $\mathrm{N}$ deficiency due to the unavailability of fertiliser $\mathrm{N}$ to the crop in year 1 . This effect was certainly exacerbated by not applying $\mathrm{N}$ fertiliser in a band next to the seed. Low rainfall for the period following the second application of $\mathrm{N}$ on 3 March 2000 (a dry period of 16 days and thereafter 2 small rainfall events of $<4 \mathrm{~mm}$ ) also reduced the effectiveness of the fertiliser. Despite the continued low pre-sowing $\mathrm{N}$ content measurements on the unfertilised treatments, substantial in-crop mineralisation of $\mathrm{N}$ in years 2 and 3 (Table 9) and water limitation as suggested by APSIM help to account for this lack of response to $\mathrm{N}$ fertiliser.

Despite no yield responses to $\mathrm{N}$ fertiliser, grain protein was maintained at a much higher concentration in the treatments that received $80 \mathrm{~kg} / \mathrm{ha}$ of fertiliser N. Grain protein in the fourth sorghum crop without additional $\mathrm{N}$ fertiliser was low at $6.7 \%$. Currently, the market does not differentiate pricing on the basis of protein concentration so there is no economic advantage for producing sorghum grain of higher protein concentration. In central Queensland, low grain protein (as low as $4.4 \%$ ) found in sorghum crop surveys reported by 
Garside et al. (1992) were related to declining soil fertility levels and age of cultivation.

\section{Residual effects of the ley pastures}

In the legume systems, soil nitrate-N was shown to decline with successive sorghum crops (Figs $1 b, 2 b, 3 b$ ), indicating crop growth and removal of $\mathrm{N}$ was depleting the initially high soil nitrate $\mathrm{N}$ levels. ICM in the M. daltoni and L. purpureus treatments declined from peaks in 1999-2000 of 71 and $127 \mathrm{~kg} / \mathrm{ha}$ of $\mathrm{N}$, to lows of 33 and $49 \mathrm{~kg} / \mathrm{ha}$ in $2002-03$, respectively (Table 9). Despite these declines, there was no response in yield to additional $\mathrm{N}$ fertiliser $(80 \mathrm{~N})$ and the experiment did not continue for long enough to measure this effect. Responses to N in 2002-03 may have also been masked by low soil water content at sowing (Table 4).

The effect of legume-based pasture leys on subsequent crop production in the northern grains belt of eastern Australia has been well documented in the literature. At Tamworth, Holford (1992) reported beneficial effects on wheat lasting for up to 9 years following a lucerne phase of 2.5-5.5 years on a Calcic Vertosol. In central Queensland on a Black Vertosol, Armstrong et al. (1999a) investigated the effect of 1-year tropical legume leys on subsequent sorghum production and found the effects to persist up to 3 crops. On much less fertile Alfisol soils in northern NSW, Whitbread et al. (2003) studied the effects of 1-season legume or fallow periods on subsequent wheat yields. They found the effects to be restricted to 1 subsequent wheat crop and explained this by the highly transient flushes of labile carbon measured after the legume phase. In the literature cited above, the beneficial effects of the legume leys have been strongly related to increases in $\mathrm{N}$ availability and soil organic matter. Soil water and seasonal conditions have also determined the response of cereal phase to the increased $\mathrm{N}$ availability. While other beneficial soil effects such as improvements in aggregate stability and hydraulic conductivity have been reported (Blair and Crocker 2000), soil structural stability of the inherently structurally stable clay soils of the northern grains belt is likely to be dominated by the management of crop residues and cover.

\section{Simulation of the crop phase}

For a cropping systems model to be useful for crop rotation studies in the semi-arid tropics, it is important that it can accurately simulate the main drivers of plant growth, namely the soil water balance, the soil $\mathrm{N}$ supply, and changes in soil organic matter, over a timeframe of several years. Importantly, this should be achievable without the need to reset soil parameters to measured values of soil water and soil nitrate-N during the simulation runs. To date, the APSIM modelling framework has been the only systems model capable of capturing these carry-over processes between successions of crops and rotations. In most situations tested in this paper, APSIM generated good estimates of grain production (Fig. $5 a$ ) and soil water (Fig. 5b), and an accurate simulation of nitrate $\mathrm{N}$ dynamics. The simulation of soil nitrate improved substantially when the grass treatments were removed from the comparison (RSME decreased from 14 to $11 \mathrm{~kg} / \mathrm{ha}$ ), which may suggest that the soil organic matter and decomposition dynamics were not simulated well under this situation of prolonged immobilisation of mineral $\mathrm{N}$ by large quantities of low quality grass residues.

Probert and McCown (2000) showed APSIM to be capable of simulating crop yields and $\mathrm{N}$ and water dynamics of dryland rotational cropping systems in southern Queensland over several seasons. The goodness of fit between measured and observed data was similar for a continuous wheat system that was modelled as either a single run from 1987 to 1996 or as a reinitialised run from measured pre-sowing water and $\mathrm{N}$ data. Foale et al. (2004) monitored soil water and $\mathrm{N}$ dynamics over 2-3 years on several on-farm fields. While there was often large variation in the measured on-farm datasets, there was generally good agreement with the long-term simulations that were developed for each of the sites.

To date, APSIM has been used to simulate the effect of preceding legume leys on subsequent crop production using 2 different approaches. In the first approach, Jones et al. (1996) used the model to simulate the entire rotation (1978-83) by simulating the legume pasture phase, its effects on soil organic matter, and the subsequent crop production. In the second method, which is the method used in this paper, Turpin et al. (1996) estimated the changes that a lucerne ley had on the soil organic matter pools and modelled crop production only during the subsequent 8 wheat crops. Both of these methods resulted in the authors concluding that the model was capable of accurately simulating crop response to $\mathrm{N}$ inputs following a legume ley. There have, however, been limited attempts to test whether the modelled legume phase changed the soil organic matter status of the soil accurately and if this can be measured and validated in the field. If simulating a grazed ley phase, the effects on soil organic matter and water are complicated by the impacts of grazing on plant production, plant litter, and manure returns and $\mathrm{N}$ losses from the system (Turpin et al. 1998).

Although the field trial described in this paper was able to measure the response of sorghum to various phases of legume pasture in 4 seasons, the long-term simulation was able to extend this to the many different climatic conditions experienced between 1954 and 2001. In all but the worst seasons, grain production following a legume ley was high and far exceeded grain produced following the grass pasture.

\section{Conclusions}

The potential for highly productive grain systems sustained by phases of productive legume pastures and beef production 
have been demonstrated through this paper and the study of Clem (2004). With widespread evidence that soil fertility is declining in this region (Dalal and Mayer 1986), and the availability of well-adapted forage legumes, it is timely that agriculturalists in the northern grains belt re-examine the potential of grain-graze systems. This paper demonstrated that APSIM is well suited to examining crop rotation systems in the semi-arid tropics. APSIM simulated the main drivers of plant growth, namely the soil water balance, the soil $\mathrm{N}$ supply and changes in soil organic matter, over a timeframe of several years without resetting the model. APSIM showed that sorghum production following a grass pasture was risky and unlikely to exceed $2000 \mathrm{~kg} / \mathrm{ha}$ of grain in $60 \%$ of seasons. Whether the effect of $\mathrm{N}$ immobilisation after a grass pasture could be overcome with effective $\mathrm{N}$ fertiliser applications should be further investigated. Sorghum production following 2-year legume leys could be expected to exceed $3000 \mathrm{~kg} / \mathrm{ha}$ of grain produced in $80 \%$ of seasons.

\section{Acknowledgments}

The financial support of ACIAR Project AS2/96/149 'Tropical Forage and Ley Legume Technology for Sustainable Grazing and Cropping Systems in Southern Africa' and the support of the project leader Dr Bruce Pengelly is gratefully acknowledged. Mrs Cristine Hall, Mr John Lawrence, and Mr Lachlan Blair are thanked for their professional technical assistance. Dr Merv Probert's suggestions on earlier drafts of the paper were gratefully received.

\section{References}

Armstrong RD, McCosker K, Johnson SB, Walsh KB, Millar B, Standley J, Probert ME (1999a) Legume and opportunity cropping systems in central Queensland. 1. Legume growth, nitrogen fixation, and water use. Australian Journal of Agricultural Research 50, 909-924. doi: 10.1071/AR98100

Armstrong RD, McCosker K, Millar B, Kuskopf S, Johnson S, Walsh K, Probert ME, Standley J (1999b) Legume and opportunity cropping systems in central Queensland. 2. Effects of legumes on following crops. Australian Journal of Agricultural Research 50, 925-936. doi: 10.1071/AR98101

Blair N, Crocker GJ (2000) Crop rotation effects on soil carbon and physical fertility of two Australian soils. Australian Journal of Soil Research 38, 71-84. doi: 10.1071/SR99064

Bremner JM (1965) Total nitrogen. In 'Methods of soil analysis. Part 2'. (Ed. CA Black) pp. 1179-1178. (American Society of Agronomy: Madison, WI)

Cameron DG (1973) Lucerne in wet soils - the effect of stage of regrowth, cultivar, air temperature and root temperature. Australian Journal of Agricultural Research 24, 851-861. doi: 10.1071/AR9730851

Carberry PS, Abrecht DG (1991) Tailoring crop models to the semi-arid tropics. In 'Climatic risk in crop production: models and management for the semi-arid tropics and subtropics'. (Eds RC Muchow, JA Bellamy) pp. 157-182. (CAB International: Wallingford)
Clem RL (2004) Animal production from legume-based ley pastures in southeastern Queensland. In 'Tropical legumes for sustainable farming systems in southern Africa and Australia'. ACIAR Proceedings No. 115. (Eds AM Whitbread, BC Pengelly) pp. 136-144. (ACIAR: Canberra)

Clem RL, Brandon NJ, Conway MJ, Jones RM, Esdale CR, Hilder TB, Robertson B, Willcocks J, Chamberlain J, Date RA, Cawley S, Taylor K, Douglas N, Darrow B (1996) Legumes for clay soils an integrated research project. Tropical Grasslands 30, 136.

Clem RL, Brandon NJ, Conway MJ, Esdale CR, Jones RM (2001) Early stage evaluation of tropical legumes on clay soils at 3 sites in central and southern inland Queensland. Tropical Agriculture Technical Memorandum No. 7. (CSIRO: Australia)

Conway MJ, Brandon NJ, Clem RL, Jones RM, Robertson BA, Willcocks JR (2001) Growth and persistence of 17 annual medic (Medicago spp.) accessions on clay soils in central Queensland. Tropical Grasslands 35, 226-234.

Crooke WM, Simpson WE (1971) Determination of ammonium in Kjeldahl digests of crops by an automated procedure. Journal of the Science of Food and Agriculture 22, 9-10.

Dalal RC, Mayer RJ (1986) Long-term trends in fertility of soils under continuous cultivation and cereal cropping in southern Queensland. I. Overall changes in soil properties and trends in winter cereal yields. Australian Journal of Agricultural Research 24, 265-279.

Dalgliesh N, Foale M (1998) 'Soil matters: Monitoring soil water and nutrients in dryland farming.' (Cranbrook Press: Toowoomba, Qld)

Dimes JP, McCown RL, Saffigna PG (1996) Nitrogen supply to no-tillage crops, as influenced by mulch type, soil type and season, following pasture leys in the semi-arid tropics. Australian Journal of Experimental Agriculture 36, 937-946. doi: 10.1071/ EA9960937

Foale MA, Probert ME, Carberry PS, Lack D, Yeates S, Brimblecombe D, Shaw R, Crocker M (2004) Participatory research in dryland cropping systems - monitoring and simulation of soil water and nitrogen in farmers' paddocks in Central Queensland. Australian Journal of Experimental Agriculture 44, 321-331. doi: 10.1071/EA02205

Garside AL, Agnew J, Chamberlain HJ, Huf S, Turnour J (1992) Yield and protein contents of grain sorghum crops in central Queensland, 1990/91 season - results and implications from a survey of commercial crops. In 'Proceedings of the second Australian Sorghum Conference'. Gatton, 4-6 February 1992. AIAS Occasional Publication No. 68. (Eds MA Foale, RG Henzell, PN Vance) pp. 311-315. (Australian Institute of Agricultural Science: Melbourne)

Holford ICR (1992) A 20 year comparison of four agricultural systems for their sustainability in the northern wheat belt. In 'Proceedings of the 6th Australian Agronomy Conference'. Armidale. (Eds KJ Hutchinson, PJ Vickery) pp. 236-239. (The Australian Society of Agronomy: Parkville, Vic.)

Irwin JAG (1974a) Crown rot of lucerne in Queensland caused by Colletotrichum trifolii. Australian Journal of Experimental Agriculture and Animal Husbandry 14, 197-200. doi: 10.1071/ EA9740197

Irwin JAG (1974b) Reaction of lucerne cultivars to Phytophthora megasperma, the cause of a root rot in Queensland. Australian Journal of Experimental Agriculture and Animal Husbandry 14, 561-565. doi: 10.1071/EA9740561

Irwin JAG (1977) Factors contributing to poor lucerne persistence in southern Queensland. Australian Journal of Experimental Agriculture and Animal Husbandry 17, 998-1003. doi: 10.1071/ EA9770998 
Jones RK, Probert ME, Dalgleish NP, McCown RL (1996) Nitrogen inputs from a pasture legume in rotations with cereals in the semiarid tropics of northern Australia: experimentation and modelling on a clay loam soil. Australian Journal of Experimental Agriculture 36, 985-994. doi: 10.1071/EA9960985

Jones RM, Rees MC (1997) Evaluation of tropical legumes on clay soils at four sites in southern inland Queensland. Tropical Grasslands 31, 95-106.

Keating BA, Carberry PS, Hammer GL, Probert ME, Robertson MJ, et al. (2003) An overview of APSIM, a model designed for farming systems simulation. European Journal of Agronomy 18, 267-288. doi: 10.1016/S1161-0301(02)00108-9

Keeny DR, Nelson DW (1982) Nitrogen - inorganic forms. In 'Methods of soil analysis. Part 2 Chemical and microbiological properties'. 2nd edn, Agronomy No. 9. (Ed. AL Page) (American Society of Agronomy and Soil Science Society of America: Madison, WI)

Lloyd DL, Gramshaw D, Hilder TB, Ludke DH, Turner JW (1985) Performance of North American and Australian lucernes in the Queensland subtropics. 3. Yield, plant survival and aphid populations in raingrown stands. Australian Journal of Experimental Agriculture 25, 91-99. doi: 10.1071/EA9850091

McNeill AM, Zhu C, Fillery IRP (1998) A new approach to quantifying the $\mathrm{N}$ benefit from pasture legumes to succeeding wheat. Australian Journal of Agricultural Research 49, 427-446. doi: 10.1071/A97072

Myers RJK (1975) Temperature effects on ammonification and nitrification in a tropical soil. Soil Biology and Biochemistry 7, 83-86. doi: 10.1016/0038-0717(75)90003-6

Northcote KH (1979) 'A factual key for the recognition of Australian soils.' 4th edn (Rellim Technical Publications: Glenside, S. Aust.)

Pengelly BC, Conway MJ (2000) Pastures on cropping soils: which tropical pasture legumes to use? Tropical Grasslands 34, $162-168$.

Probert ME, Dimes JP, Keating BA, Dalal RC, Strong WM (1998) APSIM's water and nitrogen modules and simulation of the dynamics of water and nitrogen in fallow systems. Agricultural Systems 56, 1-28. doi: 10.1016/S0308-521X(97)00028-0

Probert ME, McCown RL (2000) Evaluation of legume based strategies for profitable and sustainable grain-grazing systems using simulation modelling. Final report for GRDC, CSIRO Sustainable Ecosystems.

Raymond GE, Higginson FR (1992) 'Australian laboratory handbook of soil and water chemical methods.' (Inkata Press: Australia)
Reid RE, Sorby P, Baker DE (1986) 'Soils of the Brian Pastures Research Station Gayndah, Queensland.' Research Establishments Publication QR86004, ISSN 0813-4391. (Queensland Department of Primary Industries: Brisbane)

Robertson FA, Myers RJK, Saffigna PG (1993a) Distribution of carbon and nitrogen in a long-term cropping system and permanent pasture system. Australian Journal of Agricultural Research 44, 1323-1336. doi: 10.1071/AR9931323

Robertson FA, Myers RJK, Saffigna PG (1993b) Carbon and nitrogen mineralisation in cultivated and grassland soils in subtropical Queensland. Australian Journal of Soil Research 31, 611-619. doi: 10.1071/SR9930611

Robertson FA, Myers RJK, Saffigna PG (1994) Dynamics of carbon and nitrogen in a long-term cropping system and permanent pasture system. Australian Journal of Agricultural Research 45, 211-221. doi: 10.1071/AR9940211

Turpin JE, Probert ME, Holford ICR, Poulton PL (1996) Simulation of cereal-legume rotations using APSIM. In 'Proceedings of the 8th Australian Agronomy Conference'. pp. 562-565. (AIAS/ASA: Carlton, Vic.)

Turpin JE, Carberry PC, McCown RL, Probert ME (1998) Simulation of legume-cereal systems using APSIM. Australian Journal of Agricultural Research 49, 317-327. doi: 10.1071/A97070

Whitbread AM, Blair GJ, Konboon Y, Lefroy RDB, Naklang K (2003) Managing crop residues, fertilizers and leaf litters to improve soil $\mathrm{C}$, nutrient balances and the grain yield of rice and wheat cropping systems in Thailand and Australia. Agriculture, Ecosystems \& Environment 100, 251-263. doi: 10.1016/S01678809(03)00189-0

Whitbread A, Clem RL (2004) Grain-Graze as sustainable farming systems in sub-tropical Queensland. In 'New directions for a diverse planet. Proceedings for the 4th International Crop Science Congress'. Brisbane, Qld, 26 September-1 October 2004. (Eds T Fischer, N Turner, J Angus, L McIntyre, M Robertson, A Borrell, D Lloyd) (http://www.cropscience.org.au/)

Whitbread AM, Pengelly BC, Smith BR (2005) An evaluation of three tropical ley legumes for use in mixed farming systems on clay soils in Queensland, Australia. Tropical Grasslands 39, 9-21.

Manuscript received 27 May 2005, accepted 3 January 2006 